\title{
Medical management of obesity in Scandinavia 2016
}

Tonstad, Serena; Rössner, Stephan; Rissanen, Aila; Astrup, Arne

Published in:

Obesity Medicine

DOI:

10.1016/j.obmed.2016.01.002

Publication date:

2016

Document version

Publisher's PDF, also known as Version of record

Document license:

CC BY

Citation for published version (APA):

Tonstad, S., Rössner, S., Rissanen, A., \& Astrup, A. (2016). Medical management of obesity in Scandinavia 2016. Obesity Medicine, 1(1), 38-44. https://doi.org/10.1016/j.obmed.2016.01.002 
Review

\title{
Medical management of obesity in Scandinavia 2016
}

\author{
Serena Tonstad a , Stephan Rössner ${ }^{\mathrm{b}}$, Aila Rissanen ${ }^{\mathrm{c}}$, Arne Astrup ${ }^{\mathrm{d}, ~ *}$ \\ a Section for Preventive Cardiology, Department of Endocrinology, Morbid Obesity and Preventive Medicine, Oslo University Hospital, Oslo, Norway \\ ${ }^{\mathrm{b}}$ Apple Bay Obesity Centre, Bromma, Sweden \\ c Obesity Research Unit, Diabetes and Obesity Research Program, Biomedicum, University of Helsinki, Finland \\ ${ }^{\mathrm{d}}$ Department of Nutrition, Exercise and Sports, Faculty of Science, University of Copenhagen, Denmark
}

\section{A R T I C L E I N F O}

\section{Article history:}

Received 12 January 2016

Accepted 12 January 2016

\section{Keywords:}

Dietary supplements

Medical devices

Pharmacotherapy

Weight loss

Weight maintenance

\begin{abstract}
A B S T R A C T
Background: Preventive efforts with improved diet and more exercise have at best decelerated increasing prevalence of overweight and obesity in Scandinavia, and the complications call for more effective treatments. This review is an overview of dietary supplements, medical devices (for oral use), and pharmacological treatments approved in Scandinavian countries.

Interventions: One dietary fibre supplement, glucomannan, may produce a weight loss of $0.8 \mathrm{~kg}$ over 3 months, but a recent meta-analysis questioned efficacy. Cactus fig and white bean extracts, oral compounds that increase satiety by a fiber effect in the stomach and inhibit either fat or carbohydrate absorption, result in weight losses of $2-3 \%$ over $3-6$ months, and are generally well tolerated. The pharmaceutical compound orlistat (a lipase inhibitor) produces weight loss of $1-2 \%$ with low-dose (over-the-counter) and 3\% with high-dose (prescription), with a long-term reduction in risk of type 2 diabetes (T2D). The GLP-agonist liraglutide enhances satiety and produces weight loss of $5-7 \%$ over 6 months to 2 years, reducing comorbidities. A naltrexone/bupropion combination produces $3-5 \%$ weight loss, and reduces risk of T2D. A class of sodium-glucose co-transporter type 2 (SGLT2) inhibitor approved for the management of T2D also produces a weight loss (2-4\% over 3-6 months) by increased excretion of urinary glucose.

Conclusion: The available non-pharmacological agents produce clinically relevant weight loss, but studies are small and adverse effects are not well established. Studies of pharmacological agents that use combinations to assess additive effects on weight loss and maintenance are lacking.
\end{abstract}

() 2016 Elsevier Ltd. All rights reserved.
Obesity is an increasing health challenge at the global level, and the Scandinavian countries are no exception. About $15-25 \%$ of the adult population can be classified as obese (BMI $\left.>30 \mathrm{~kg} / \mathrm{m}^{2}\right)$, and the majority of the population is overweight (BMI $>25 \mathrm{~kg} / \mathrm{m}^{2}$ ), which causes numerous comorbidities, disability, and reduced life expectancy. While prevention of weight gain, overweight and obesity is preferred, there are only early indications of a leveling off of the increase in prevalence, and a large part of the obese population is seeking treatment. Many obese individuals manage to lose weight by following various diet and exercise programs, commercial weight loss plans, and using meal replacements, but there is an increasing demand for adjunct therapy that can enhance initial

\footnotetext{
* Corresponding author. Department of Nutrition, Exercise and Sports, Faculty of Science, University of Copenhagen, Rolighedsvej 26, 1958 Frederiksberg C, Denmark.

E-mail address: ast@nexs.ku.dk (A. Astrup).
}

weight loss efforts and improve long term weight loss maintenance. Bariatric surgery is an option for morbidly obese patients, but the majority of obese subjects do not fulfill the criteria for such surgical interventions. For some patients this gap may be bridged with dietary supplements, medical devices, and pharmacological compounds. The purpose of this review is to provide an update on the management options available in Scandinavia, and present a brief assessment of efficacy and safety, and clinical directions for choices for the individual patient.

When previously approved pharmaceutical agents such as sibutramine and rimonabant were withdrawn from the market due to potential serious adverse effects, only orlistat and amfepramone were left. However, in 2015 two new compounds were approved in the EU for weight reduction: liraglutide $3 \mathrm{mg}$ (Saxenda ${ }^{\mathbb{R}}$ ), and naltrexone/bupropion (Mysimba ${ }^{\circledR}$ ). We therefore present a brief updated summary of the use of orlistat and amfepramone, and a section on the two novel compounds. Furthermore for patients with S, the GLP-1 analogues and SGLT2 inhibitors are available, 
providing both glucose control and weight loss. Moreover, a number of dietary supplements and medical devices have been approved for weight control, and these products are also reviewed. We have included products available in at least two Scandinavian countries.

\section{Pharmaceutical compounds}

\subsection{Orlistat (Xenical ${ }^{\mathbb{R}}$, Alli $^{\mathbb{R}}$ )}

Orlistat has withstood the test of time, remaining the only approved therapy in Europe since 1998 for long-term treatment of obesity. Orlistat potently and selectively inhibits gastric and intestinal lipase, reducing intestinal fat absorption. While orlistat's inhibition of intestinal fat absorption is minimal when dietary fat intake is very low, the proportion of fat excretion increases in a dose-dependent manner with increasing dietary fat, reaching a plateau of about 30\% with the usual dose of $120 \mathrm{mg}$ three times daily (Hauptman et al., 1992). In addition, orlistat may increase glucagon-like peptide 1 secretion (Damci et al., 2004).

\subsubsection{Weight loss efficacy}

In a meta-analysis of 16 randomized, placebo-controlled trials of $\geq 1$ year orlistat reduced body weight by $2.9 \mathrm{~kg}$ (95\% confidence interval [CI] 2.5-3.2 kg) compared with placebo (Rucker et al., 2007). In a recent systematic review of studies with at least 50 participants per group and at least $50 \%$ retention, an intention-totreat analysis found that orlistat gave a $3.4 \mathrm{~kg}$ greater weight loss (3.1\% of initial weight) than placebo (Yanovski and Yanovski, 2014). Two trials of orlistat $60 \mathrm{mg}$ three times daily found a $2.5 \mathrm{~kg}$ greater weight loss than with placebo at 12 months (Yanovski and Yanovski, 2014). In patients with T2D, the difference between orlistat and placebo was about $2 \mathrm{~kg}$ (Norris et al., 2005; Jacob et al., 2009).

\subsubsection{Weight maintenance}

In a trial in 3304 participants most of the weight loss difference at 1 year (11.4 kg for orlistat versus $7.5 \mathrm{~kg}$ for placebo) was preserved in those that completed all four years of the study (6.9 kg for orlistat versus $4.1 \mathrm{~kg}$ for placebo) (Torgerson et al., 2004). Other trials have looked specifically at orlistat as a weight maintenance treatment following weight loss induced by orlistat, conventional dieting or a very low energy diet (VLED). In one trial orlistat administered for three years after VLED significantly reduced weight regain compared to placebo (4.6 kg versus $7.0 \mathrm{~kg}$ ) (Richelsen et al., 2007). A meta-analysis found that orlistat effectively maintained weight loss at 12 months, with a difference of $1.8 \mathrm{~kg}$ (95\% CI 1.06 to 2.54) compared to placebo (Dombrowski et al., 2014).

\subsubsection{Glycemic control in $T 2 D$}

In a retrospective analysis involving 2550 overweight or obese patients with T2D, participants treated with orlistat for 6-12 months had significantly larger decreases in HbA1c compared to placebo ( $-0.74 \%$ vs. $-0.31 \%$ ) (Jacob et al., 2009).

\subsubsection{Prevention of $T 2 D$}

In a 4-year randomized, controlled trial, orlistat added to lifestyle changes resulted in a $37.3 \%$ reduction in the incidence of T2D (Torgerson et al., 2004). Pooled data from three studies has indicated that orlistat prevented progression to diabetic status in subjects with impaired glucose tolerance (Heymsfield et al., 2000).

\subsubsection{Cardiovascular risk factors}

Orlistat improves most cardiovascular risk factors. Reductions in visceral fat (Tiikkainen et al., 2004), LDL cholesterol (Muls et al.,
2001) and glycemia (Jacob et al., 2009), and improved insulin sensitivity (Kelley et al., 2004), appear in part to be independent of weight loss. In patients with hypertension, orlistat improved systolic blood pressure by $-2.5 \mathrm{~mm} \mathrm{Hg}(95 \% \mathrm{CI}, 4.0$ to $-0.9 \mathrm{mmHg})$ and diastolic blood pressure by $-1.9 \mathrm{~mm} \mathrm{Hg}(95 \% \mathrm{CI}-3.0-0.9 \mathrm{mmHg})$ (Siebenhofer et al., 2013). A recent meta-analysis found that orlistat increased adiponectin and reduced leptin and C-reactive protein (Derosa et al., 2015).

\subsubsection{Safety and tolerability}

Gastrointestinal effects including oily spotting, flatus with discharge, fecal urgency and steatorrhea are common, though they tend to subside as patients learn to adjust fat intake. The risk ratio for discontinuation of orlistat compared to placebo due to adverse events in randomized controlled trials was 1.59 (95\% CI, 1.21-2.08), with a number need to harm of 39 (95\% CI, 25-83) (Johansson et al., 2009). Rare cases of liver injury have been reported. However, the UK Clinical Practice Research Datalink found no evidence of an increased risk of liver injury (Douglas et al., 2013). Orlistat interferes with the absorption of several drugs and fat-soluble vitamins (Filippatos et al., 2008) and may cause acute kidney injury (Kwan et al., 2013).

\subsubsection{Clinical use}

Orlistat is indicated for the treatment of obesity (BMI $\geq 30 \mathrm{~kg} /$ $\mathrm{m}^{2}$ ) or overweight (BMI $27-29.9 \mathrm{~kg} / \mathrm{m}^{2}$ ) with associated risk factors, in conjunction with a modestly fat-reduced diet. Attrition rates are high, mostly due to high cost and side effects (Padwal et al., 2007), as well as difficulty in complying with dietary recommendations (Svendsen et al., 2009) and the popularity of low carbohydrate diets. A study suggested that a low-carbohydrate ketogenic diet leads to similar weight loss as orlistat combined with a low fat diet (Yancy et al., 2010). Beneficial long-term effects of orlistat on cardiovascular disease parameters have not been demonstrated.

\subsection{Amfepramone}

Amfepramone (diethylpropion) is approved in the EU for treatment of obesity for short durations (4-6 weeks and no longer than 3 months) under various brand names (Anorex ${ }^{\circledR}$, Dobesin ${ }^{\circledR}$, Regenon ${ }^{\circledR}$ etc.). The drug is closely related to amphetamines and possesses some of the same CNS stimulant properties and abuse potential, and has been associated with serious cases of primary pulmonary hypertension. In 1999 the Committee for Proprietary Medicinal Products (CPMP) recommended a stop to the use of amfepramone for obesity treatment and a stop to the sale of this drug in EU countries. In the Scandinavian countries it is available only in Denmark, but its use cannot be recommended.

\subsection{Liraglutide $3 \mathrm{mg}\left(\right.$ Saxenda $^{\circledR}$ )}

GLP-1 is an endogenous hormone released from L-cells in the small intestine in response to the presence of food (peptides and monoglycerates), and it acts both as an incretin that stimulates the postprandial release of insulin, and as a satiety hormone. It is cleared from the bloodstream within minutes, but injectable agonists have been developed that can be given once daily, or even only once weekly, and a number of such agents have been approved for the management of T2D (e.g. exenatide, liraglutide). GLP-1 agonists in dosages used for treatment of T2D have been found to produce a small weight loss (Wang et al., 2014). Liraglutide is used in the doses 1.2 and $1.8 \mathrm{mg}$ daily for T2D (Victoza ${ }^{\circledR}$ ), but higher dosages are required for a clinically relevant weight loss in obese patients (i.e. $3 \mathrm{mg}$ ). 
1.3.1. Weight loss efficacy. A large phase III program (SCALE) using liraglutide $3 \mathrm{mg}$ daily was based on a phase II program that demonstrated that the dose of $3 \mathrm{mg}$ was effective for weight control over one year in obese patients (Astrup et al., 2009; Scheen, 2015). Liraglutide $3 \mathrm{mg}$ produced a mean weight loss of $8 \mathrm{~kg}$ as compared to $2 \mathrm{~kg}$ in the placebo group, and $4 \mathrm{~kg}$ in the orlistat reference group (Scheen, 2015) (Fig. 1). After two years follow-up the weight loss was $5.3 \mathrm{~kg}$ with liraglutide and $2.3 \mathrm{~kg}$ with orlistat (Fig. 1) (Astrup et al., 2012). The group which received placebo for the first year and subsequently switched to liraglutide achieved a weight loss that was indistinguishable from the group which had received liraglutide $3 \mathrm{mg}$ from the start. After two years $52 \%$ of the patients on liraglutide $3 \mathrm{mg}$ had maintained more than 5\% weight loss, and $26 \%$ more than $10 \%$. The prevalence of prediabetes and metabolic syndrome was reduced, and so were blood pressure and lipids following liraglutide as compared with placebo (Fig. 2).

1.3.2. Safety and tolerability. The effects of liraglutide are well known from the use of lower dosages for T2D. Side effects are mainly gastrointestinal with nausea, vomiting, obstipation, and diarrhea, which are mild and transient in nature in most cases (Shyangdan et al., 2010). The adverse effects can be reduced by a slow up-titration of the dosage. Independent of dosage liraglutide increases heart rate by 2-4 bpm, but meta-analyses have found that liraglutide is associated with reduced incidence of cardiovascular events (Monami et al., 2014). A slightly increased risk of pancreatitis has been reported with the use of liraglutide and other GLP-1 agonists. For liraglutide $3 \mathrm{mg}$ the incidence was 0.4 cases per 100 patient-years treatment as compared to ca. $0.1 \%$ with placebo (Pi-Sunyer et al., 2015).

1.3.3. Clinical use. Victoza ${ }^{\circledR}$ which is the trade name for liraglutide in doses of 1.2 or $1.8 \mathrm{mg}$ per day is indicated for the treatment of T2D and not indicated for the treatment of overweight or obesity. Saxenda ${ }^{\circledR}$, on the other hand, is the trade name for liraglutide in the dose of $3 \mathrm{mg}$ per day for the treatment of obesity or overweight (BMI $\geq 27 \mathrm{~kg} / \mathrm{m}^{2}$ ) with weight-related comorbidities. The weight loss that occurs on diet and liraglutide during the first 3-12 weeks is a good predictor of the individual long term outcome, and if the patient fails to lose at least $5 \%$ of initial body weight after 3 months the treatment should be discontinued.

The manufacturer of liraglutide recommends that Saxenda ${ }^{\circledR}$ be used especially for subjects with BMI $\geq 35 \mathrm{~kg} / \mathrm{m}^{2}$ and weightrelated comorbidities such as hypertension, dyslipidemia or obstructive sleep apnea. The argument is that this group of patients suffers the most from their obesity and therefore these patients are in particular need of treatment. Generally, health authorities in many countries have acknowledged the imminent need for treatment of people with $\geq 35 \mathrm{~kg} / \mathrm{m}^{2}$, as exemplified by reimbursement of bariatric surgery for this particular group of patients. However, reimbursement of liraglutide through public monies is not yet available in Scandinavia.

\section{Pharmaceutical combinations in obesity treatment}

Several reasonably effective anti-obesity drugs have been withdrawn from the market because of unacceptable side effects. At the same time no novel, effective anti-obesity drug can be foreseen. It is therefore understandable that the pharmaceutical industry has been looking for ways to recycle old and wellestablished drugs, which are already approved for other clinical indications. This saves time and toxicology work to establish safety, and hence is cost-effective. Two such products have recently been developed. Qsiva ${ }^{\circledR}$ is a combination of topiramate and phentermine, but in considerably lower doses than when used for their initial indications. The observation of weight loss in patients treated with topiramate for epilepsy led to attempts to develop topiramate into an anti-obesity drug. This was not successful at the usual dosage levels used because of side effects (Astrup et al., 2004), which then led to attempts to combine low dose topiramate with another compound instead. Phentermine has been widely used for short-term treatment of obesity for decades. In a low dose combination the compounds were found to potentiate their effects on weight loss, and the product was eventually released as Qnexa ${ }^{\mathbb{R}}$, later Qsiva ${ }^{\circledR}$ in the US and some other countries (Jordan et al., 2014). However, European regulating authorities determined that the potential side effects were not documented well enough and the drug has not been approved in EU. Therefore it will not be further discussed here. However, the other drug combination, which indeed has been approved in the EU, will be presented below.

\subsection{Naltrexone/bupropion (Mysimba ${ }^{\circledR}$ )}

Mysimba $^{\circledR}$ is a combination of two compounds (Naltrexone $7.2 \mathrm{mg}$ /bupropion $78 \mathrm{mg}$ ), each of which has been previously approved for clinical indications other than weight loss. Both compounds appear as extended release forms (ER). Naltrexone is an opioid receptor antagonist blocking all three opioid receptors. The compound is currently used in the treatment of alcohol dependence. For this indication the dosage is $50 \mathrm{mg}$ daily. Bupropion is an

\section{Weight loss for different treatment interventions}

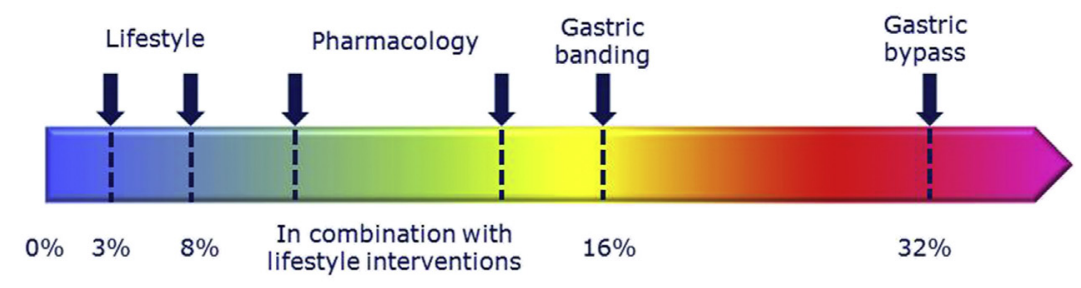

Magnitude of weight loss (\%)

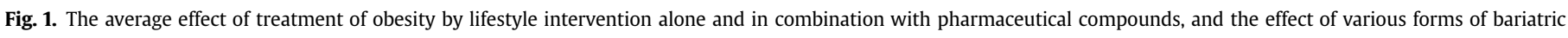
surgery. 

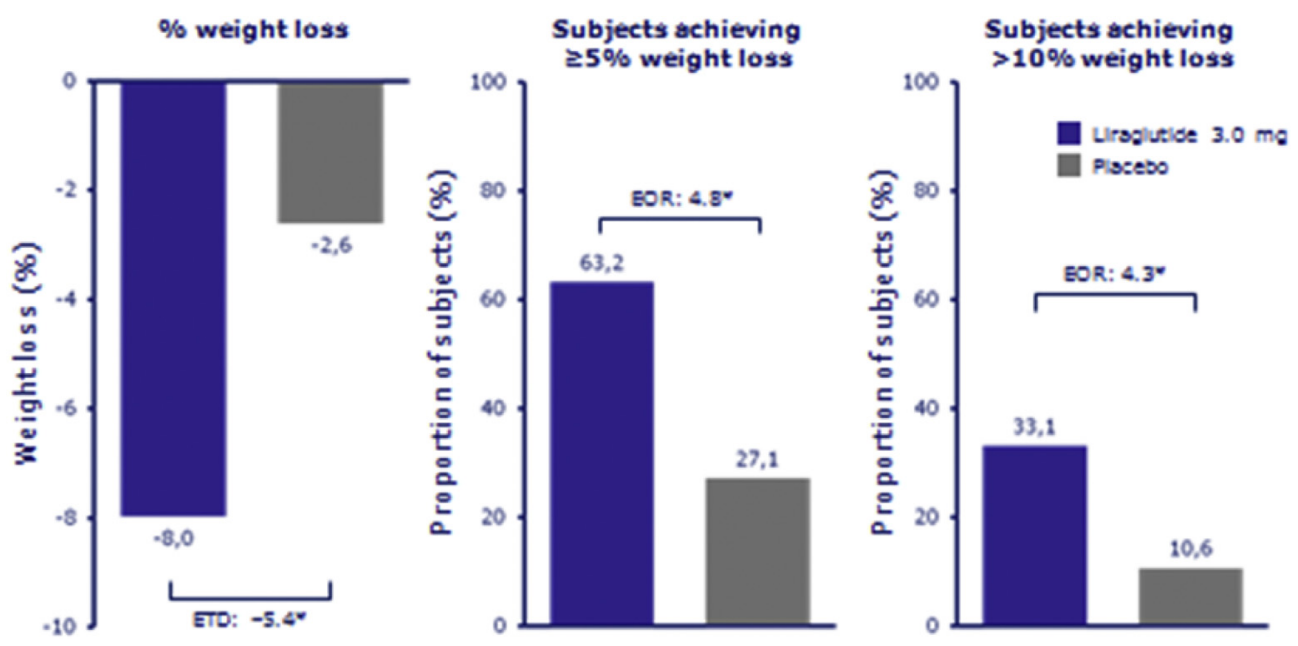

Fig. 2. Treatment with liraglutide $3 \mathrm{mg}$ for one year induces an average weight loss of $8 \mathrm{~kg}$ compared to $2 \mathrm{~kg}$ in a placebo group. Also shown are the percentage of subjects with weight loss of $\geq 5 \%$ and $\geq 10 \%$ in liraglutide $3 \mathrm{mg}$ groups vs. placebo.

antidepressant which has been used for several indications in addition to the mood effect, such as smoking cessation and as an adjunct in treatment of attention deficit hyperactivity disorder. Bupropion is an uptake inhibitor of dopamine and noradrenaline in the central nervous system. The drug also acts as a nicotine antagonist on the acetylcholine receptor causing nicotine dependence. The dosage for these indications ranges around $150-300 \mathrm{mg}$ daily.

The combination of the two compounds has a synergistic effect in the treatment of obesity and leads to weight reduction, although the dose of each compound is far lower than the dosages for the initial indications. When given together their action reduces appetite, and possibly also increases energy expenditure, leading to a negative energy balance and ensuing weight loss (Yanovski and Yanovski, 2015). With weight loss the anticipated effects of improvement of obesity-associated risk factors have been observed. In 2015 the EU approved Mysimba ${ }^{\circledR}$ for use in the entire EU region. In summarizing the characteristics of the drug the committee concluded that although the weight loss effects were modest, they were still clinically significant.

\subsubsection{Clinical use}

Mysimba ${ }^{\circledR}$ is indicated, as an adjunct to a reduced-calorie diet and increased physical activity, for weight loss treatment in adult patients ( $\geq 18$ years) with a BMI of $\geq 30 \mathrm{~kg} / \mathrm{m}^{2}$ (obese), or $\geq 27 \mathrm{~kg}$ / $\mathrm{m}^{2}$ to $<30 \mathrm{~kg} / \mathrm{m}^{2}$ (overweight) in the presence of one or more weight-related co-morbidities (e.g.T2D, dyslipidemia, or controlled hypertension). Mysimba ${ }^{\circledR}$ is administered in gradually increasing doses from one tablet daily with a meal to the maximum dose of two tablets twice daily. Treatment with Mysimba ${ }^{\circledR}$ should be discontinued after 16 weeks if patients have not lost at least $5 \%$ of their initial body weight.

\subsubsection{Adverse effects}

There was a certain concern about the possible side effects of the drug (cardio-vascular complications and a slightly increased risk of epileptic fits) but the committee concluded that these could be managed simply by drug withdrawal. In clinical practice modest nausea seems to be the main side effect.

\subsection{Sodium-glucose co-transporter type 2 (SGLT2) inhibitors}

Weight loss is of prime importance for patients with T2D, of whom the majority are either overweight or obese. The choice of antidiabetic medication should aim at weight neutrality or reduction, such as GLP-1 receptor agonists and sodium-glucose cotransporter type 2 inhibitors. SLGT2 inhibitors (dapagliflozin, canagliflozin and empagliflozin, currently available in Scandinavia), are novel antidiabetic agents that induce a small weight loss. They increase glucose excretion into the urine and reduce hyperglycemia by inhibiting renal SGLT2 that is responsible for the reabsorption of most of the glucose (Scheen, 2015). The currently available SGLT2inhibitors have similar pharmacologic characteristics.

\subsubsection{Clinical efficacy and use}

It is well documented that SGLT2-inhibitors reduce $\mathrm{HbA}_{1}$ by $0.7-1.0 \%$ from a mean of $7.5-9.0 \%$ in T2D patients treated with diet and exercise, or with any glucose-lowering agents (Scheen, 2015). Due to the increased caloric loss associated with reduced renal reabsorption of glucose, SGLT2-inhibitors induce weight loss in overweight and obese patients with T2D (Barnett, 2013). An early weight loss of $1-2 \mathrm{~kg}$ is usually seen as a result of osmotic and diuretic fluid loss upon the initiation of therapy by any SGLT2inhibitor. However, reduction of body weight by weeks 24 and thereafter, amounting to an average of about $2-4 \mathrm{~kg}$, now welldocumented up to four years, has been shown to be predominantly due to loss of fat mass.

\subsubsection{Safety and tolerability}

In studies with SLGT2-inhibitors a slight reduction of systolic and diastolic blood pressure has been documented. The effect of empagliflozin on cardiovascular morbidity and mortality has recently been reported in a study of 7020 patients with T2D, followed for an average of three years. As compared to placebo, empagliflozin resulted in a significantly lower risk of cardiovascular and total death (HR $0.62,95 \% \mathrm{CI}: 0.49$ to 0.77 , and $0.68,95 \% \mathrm{CI} 0.57$ to 0.82 ), as well as hospitalization for heart failure ( $\mathrm{HR} 0.65,95 \% \mathrm{CI}$ : 0.50 to 0.85 ) (Zinman et al., 2015).

SLGT2-inhibitors are usually well tolerated. They slightly increase the risk of urinary tract and genital infections, which however are usually mild and clinically manageable (Scheen, 2015). 


\section{Dietary supplements}

\subsection{Glucomannan (Allévo ${ }^{\circledR}$, Kilo Trim ${ }^{\circledR}$, XLS Medical Appetite Reducer $^{(B)}$ etc.)}

Glucomannan or konjac mannan is dietary fiber that has been found to enhance satiety and produce weight loss, and it is approved by EFSA for weight loss in EU (EFSA, 2010). Glucomannan is a soluble-type of fiber that forms a viscous, gel-like mass in the stomach when hydrated, and this gel seems to delay gastric emptying and induce satiety, leading to a decrease in subsequent energy intake (EFSA, 2010). EFSA concluded that in order to obtain a weight loss at least $3 \mathrm{~g}$ of glucomannan should be consumed daily in three doses of at least $1 \mathrm{~g}$ each, together with 1-2 glasses of water before meals, together with an energy-restricted diet (EFSA, 2010). The target population is overweight adults. The products we assessed on the market did not declare the content of glucomannan, and we found it questionable that they provide the required 3 g per day.

The evidence to substantiate the weight loss claim seems weak. There are no studies lasting more than 3 months. A meta-analysis from 2008 found a significant weight loss by glucomannan of $0.79 \mathrm{~kg}$ greater than placebo (Sood et al., 2008). However, more recent and updated meta-analyses of the randomized trials did not find that glucomannan added any weight loss to a diet (Zalewski et al., 2015a, 2015b) (Table 1).

\section{Medical devices}

\subsection{Cactus fig extract (Litramine ${ }^{\circledR}, X L S$ Medical Fat Binder ${ }^{\circledR}$ )}

Litramine ${ }^{\circledR}$ is patented fiber complex made from dry leaves of the fig cactus opuntia ficus-indica. The leaves from this cactus are rich in fiber which can bind to fat in the upper part of the

Table 1

Approved dietary supplements, medical devices and pharmacotherapy for management of overweight and obesity in Scandinavian countries.

\begin{tabular}{|c|c|c|c|c|c|}
\hline Compound & Mechanism of action & $\begin{array}{l}\text { Effects on weight } \\
\text { above placebo }\end{array}$ & Adverse effects & Status & Comments \\
\hline $\begin{array}{l}\text { Dietary supplements } \\
\text { Glucomannan } \\
\text { (Allévo }^{\circledR}, \text { Konjak tabletter }^{\circledR} \text {, } \\
\text { XLS Medical Appetite } \\
\left.\text { Reducer }{ }^{\circledR b} \text { etc. }\right)\end{array}$ & Gel-forming fiber & $\begin{array}{l}0-0.8 \mathrm{~kg} \text { over } \\
3 \text { months }\end{array}$ & $\begin{array}{l}\text { Loose stools and } \\
\text { diarrhea. Tablets may } \\
\text { cause GI blockage due } \\
\text { to swelling }\end{array}$ & $\begin{array}{l}\text { Approved by } \\
\text { EFSA (EU) for weight } \\
\text { loss claim providing an } \\
\text { intake of } 3 \mathrm{~g} / \text { day }\end{array}$ & $\begin{array}{l}\text { None of the products have } \\
\text { declared their content of } \\
\text { glucomannan, and it is } \\
\text { questionable they provide } 1 \mathrm{~g} / \\
\text { dose. Newer meta-analyses } \\
\text { question any weight loss } \\
\text { efficacy of } 3 \mathrm{~g} / \text { day. }\end{array}$ \\
\hline $\begin{array}{l}\text { Medical devices } \\
\text { Cactus fig fiber } \\
\quad(\text { Opuntia ficus-indica) } \\
\text { (Litramine }^{\circledR}, \text { XLS Medical } \\
\left.\quad \text { Fat Binder }^{\circledR}\right)\end{array}$ & $\begin{array}{l}\text { Fat binder plus appetite } \\
\text { suppressant } \\
\text { (dietary fiber and plant } \\
\text { extracts from } \\
\text { Opuntia ficus-indica) }\end{array}$ & $\begin{array}{l}2-3 \% \text { over } 3-6 \\
\text { months }\end{array}$ & Well tolerated & $\begin{array}{l}\text { Approved medical } \\
\text { device }\end{array}$ & Long term studies lacking \\
\hline $\begin{array}{l}\text { White bean } \\
\quad \text { (Phaseolus vulgaris) } \\
\text { extract. } \\
(\text { XLS Medical } \\
\left.\text { Carb Blocker }{ }^{\circledR}\right)\end{array}$ & Alpha-amylase inhibitor & $2 \%$ over 6 months & $\begin{array}{l}\text { Gastrointestinal } \\
\text { symptoms (bloating } \\
\text { and constipation) }\end{array}$ & $\begin{array}{l}\text { Approved medical } \\
\text { device }\end{array}$ & Long term studies lacking \\
\hline \multicolumn{6}{|l|}{$\begin{array}{l}\text { Pharmaceutical } \\
\text { compounds }\end{array}$} \\
\hline $\begin{array}{l}\text { Orlistat } \\
\left(\text { Alli }^{\circledR}, \text { Xenical }^{\circledR}\right)\end{array}$ & Lipase-inhibitor & $\begin{array}{l}1-2 \% \text { for low-dose } \\
60 \mathrm{mg}\left(\text { Alli }^{\circledR}\right) \\
\text { and } 3 \% \text { for high- } \\
\text { dose } 120 \mathrm{mg} \\
\left(\text { Xenical }^{\circledR}\right)\end{array}$ & $\begin{array}{l}\text { Gastrointestinal } \\
\text { symptoms (diarrhea, } \\
\text { oily leakage if non- } \\
\text { compliant) }\end{array}$ & $\begin{array}{l}\text { Approved in EU: } \\
\text { high dose on } \\
\text { prescription, } \\
\text { low dose OTC }\end{array}$ & $\begin{array}{l}\text { Long-term studies support } \\
\text { efficacy and safety over } \\
4 \text { years }\end{array}$ \\
\hline $\begin{array}{l}\text { Liraglutide } 3 \mathrm{mg} \\
\left(\text { Saxenda }{ }^{\mathbb{R}}\right)\end{array}$ & $\begin{array}{l}\text { GLP-agonist - enhances } \\
\text { satiety and reduces } \\
\text { energy intake }\end{array}$ & $\begin{array}{l}5-7 \% \text { over } 3-12 \\
\text { months }\end{array}$ & $\begin{array}{l}\text { GI symptoms (nausea, } \\
\text { vomiting). Dose- } \\
\text { related }\end{array}$ & $\begin{array}{l}\text { Approved on } \\
\text { prescription in } \\
\text { USA and EU }\end{array}$ & Injectable, once daily \\
\hline 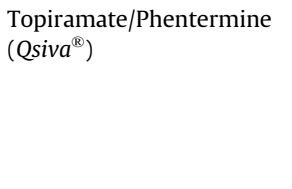 & $\begin{array}{l}\text { Reduced energy intake by } \\
\text { suppression of appetite }\end{array}$ & $7-8 \%$ over $1-2$ years. & $\begin{array}{l}\text { Phentermine: } \\
\text { cardiovascular } \\
\text { stimulation. } \\
\text { Topiramate: } \\
\text { CNS-related } \\
\text { side effects }\end{array}$ & $\begin{array}{l}\text { Approved on } \\
\text { prescription } \\
\text { in the US, not EU }\end{array}$ & \\
\hline $\begin{array}{l}\text { Naltrexone/bupropion } \\
\left(M y \operatorname{simb} a^{\mathbb{B}}\right)\end{array}$ & $\begin{array}{l}\text { Reduced energy intake by } \\
\text { suppression of appetite }\end{array}$ & $\begin{array}{l}3-5 \% \text { over } 3-6 \\
\text { months }\end{array}$ & $\begin{array}{l}\text { GI symptoms, dry } \\
\text { mouth }\end{array}$ & $\begin{array}{l}\text { Approved on } \\
\text { prescription in US } \\
\text { and EU }\end{array}$ & $\begin{array}{l}\text { Concern about long term } \\
\text { side effects }\end{array}$ \\
\hline $\begin{array}{l}\text { SGLT-2 Inhibitors } \\
\text { (Dapagliflozin, } \\
\text { Canagliflozin, } \\
\text { Empagliflozin) }\end{array}$ & $\begin{array}{l}\text { Increased excretion of } \\
\text { glucose in urine }\end{array}$ & $\begin{array}{l}2-4 \% \text { over } 3-6 \\
\text { months, } \\
\text { maintained } \\
\text { for up to } 4 \text { years }\end{array}$ & $\begin{array}{l}\text { Urinary tract and } \\
\text { genital infections }\end{array}$ & $\begin{array}{l}\text { Approved for T2D, } \\
\text { not for non-diabetic } \\
\text { obesity. }\end{array}$ & \\
\hline
\end{tabular}

${ }^{a}$ For the pharmaceutical compounds the weight loss efficacy results are based on large-scale studies, whereas the studies for dietary supplements and medical devices generally are small and of short-term duration.

b XLS Medical Appetite Reducer is licensed as a medical device 
gastrointestinal tract. In the stomach it seems that this complex is enclosed in a gel covering, which can no longer be absorbed and hence is eliminated undigested while trapping some fat, helping in achieving a negative energy balance. Some studies suggest that Litramine ${ }^{\circledR}$ also has a satiety effect since the gel results in a more firm structure of the intestinal content, causing a delay in stomach emptying and therefore possibly a longer feeling of satiety. Litramine ${ }^{\circledR}$ is not absorbed in the body and in the reported clinical studies tolerability has been rated as very good with few exceptions. In a recent review the efficacy and safety of Litramine ${ }^{\circledR}$ has been summarized by the research group from which most of the published work on this compound stems (Chong et al., 2014).

In a study by Uebelhack et al. (2014) the dietary fat binding capacity of Litramine ${ }^{\circledR}$ fiber was determined through analysis of fecal fat excretion in healthy volunteers. Two 24-hour feces samples were collected during both the baseline and treatment periods for analysis of the fat content. Subjects given cactus fiber showed a significantly increased fecal fat excretion compared with placebo ( $16 \%$ vs $5 \%, P<0.001)$. In a three-month study 123 obese overweight subjects were treated with Litramine ${ }^{\circledR}$ or placebo (Grube et al., 2013).

The study comprised a two-week run-in phase and an initial $12-$ week trial phase. The initial BMI-value of the group was $29.6 \mathrm{~kg} / \mathrm{m}^{2}$ and the middle age 45 years. The mean body weight change from baseline was $3.8 \pm 1.8 \mathrm{~kg}$ in the Litramine ${ }^{\circledR}$ group vs. $1.4 \pm 2.6 \mathrm{~kg}$ in the controls $(\mathrm{p}<0.001)$, and $76 \%$ of subjects on Litramine ${ }^{\circledR}$ versus $28 \%$ on placebo lost at least $3 \%$ of the body weight $(\mathrm{p}<0.001)$. Another double-blind, randomized, placebo-controlled study in overweight and obese subjects lasting 24 weeks demonstrated that after 24 weeks the number of responders was higher in Litramine ${ }^{\circledR}$ _ treated subjects than in placebo individuals. At the end of the study the difference in weight between the groups was $2.2 \mathrm{~kg}$; $92 \%$ in the Litramine ${ }^{\circledR}$ group vs. $25 \%$ in controls managed to maintain the weight loss (Grube et al., 2015).

The Litramine ${ }^{\circledR}$ dose is 2 tablets three times daily, which means drug intake with every meal, since the compound is intended to interfere with fat absorption and satiety feelings in connection with ordinary food intake.

\subsection{White bean extract - Phaseolus vulgaris (XLS Medical Carb Blocker $^{\mathbb{R}}$ )}

A number of drugs (e.g. acarbose) and naturally occurring food components contain alpha-amylase inhibitors and are used to reduce post-prandial blood glucose excursions, enhance satiety by reducing the glycemic index of meals, and to reduce the absorption of carbohydrate to increase the loss of calories from the GI tract. Common beans contain various forms of alpha-amylase inhibitors, and extracts have been developed to increase the efficacy of the enzyme inhibition to achieve clinical efficacy. In particular, an extract from the white bean (Phaseolus vulgaris) has been tested in a number of trials (for review see Barrett and Udani, 2011). A four week, placebo-controlled, RCT trial in 25 subjects found a nonsignificant weight loss difference of $0.6 \mathrm{~kg}$ in favor of the white bean extract, but among the subjects with a high carbohydrate intake the difference was more pronounced ( $3 \mathrm{~kg}$ ) (Udani and Singh, 2007). A subsequent 12 week, double-blind, placebocontrolled RCT randomized 124 subjects with a BMI $25-35 \mathrm{~kg} / \mathrm{m}^{2}$ to a supplement with white bean extract in combination with a mild diet (Grube et al., 2014). After the 12 week weight loss intervention weight loss was 2.91 versus $0.92 \mathrm{~kg}$, in the verum and placebo groups respectively ( $\mathrm{P}<0.001)$. The weight loss in favor of the white bean extract, $2.0 \mathrm{~kg}$, was due mainly to a reduction in body fat mass of $1.6 \mathrm{~kg}$, which was also reflected in a $1.4 \mathrm{~cm}$ reduction in waist circumference. In a subsequent 24 weeks, open label, weight maintenance follow-up phase the majority of subjects maintained the weight loss. The adverse events were few and probably unrelated to the treatment.

\section{Conclusion}

In addition to diet, exercise, and behavior modification, a number of treatment options are available for overweight and obese patients who do not qualify for bariatric surgery. For overweight subjects dietary supplements (approved as medical devices) provide an option that adds $2-3 \%$ (or $\mathrm{kg}$ ) to the diet-induced weight loss, and slightly more with orlistat, the use of which, however requires a strict low-fat diet to avoid tolerability problems due to GI tract side effects. These compounds act locally in the gastrointestinal tract, and have not been found to possess systemic adverse effects. The newer pharmaceutical agents provide more weight loss, and large-scale studies are available to document long-term effects, effects on prevention of T2D, and better safety information in general. We conclude that studies of the non-pharmacological agents are generally small in size, and adverse effects are not well established. In regard to pharmacological agents, there is a lack of studies that combine the available treatment options to assess additive effects on weight loss and maintenance.

\section{References}

Astrup, A., Carraro, R., Finer, N., Harper, A., Kunesova, M., Lean, M.E.J., Niskanen, L. Rasmussen, M.F. Rissanen, A., Rössner, S., Savolainen, M.J., Van Gaal, L., on behalf of the NN8022-1807 Investigators, 2012. Safety, tolerability and sustained weight loss over 2 years with the once-daily human GLP-1 analog, liraglutide. Int. J. Obes. 36, 843-854.

Astrup, A., Caterson, I., Zelissen, P., Guy-Grand, B., Carruba, M., Levy, B., Sun, X., Fitchet, M., 2004. Topiramate: long-term maintenance of weight loss induced by a low-calorie diet in obese subjects. Obes. Res. 12, 1658-1669.

Astrup, A., Rössner, S., Van Gaal, L., Rissanen, A., Niskanen, L. Al Hakim, M. Madsen, J., Rasmussen, M.F., Lean, M.E.J., on behalf of the NN8022-1807 Study Group, 2009. Effects of liraglutide in the treatment of obesity: a randomised, double-blind, placebo-controlled study. Lancet 374, 1606-1616.

Barnett, A.H., 2013. Impact of sodium glucose cotransporter 2 inhibitors on weight of patients with type 2 diabetes mellitus. Postgrad. Med. 125, 433-442.

Barrett, M.L., Udani, J.K., 2011. A proprietary alpha-amylase inhibitor from white bean (Phaseolus vulgaris): a review of clinical studies on weight loss and glycemic control. Nutr. J. 10, 24.

Chong, P.W., Lau, K.Z., Gruenwald, J., Uebelhack, R., 2014. A review of the efficacy and safety of Litramine IQP-G-002AS, an opuntia ficus-indica derived fiber for weight management. Evid. Based Complement. Altern. Med. 2014, 943713.

Damci, T., Yalin, S., Balci, H., Osar, Z., Korugan, U., Ozyazar, M., Ilkova, H., 2004. Orlistat augments postprandial increases in glucagon-like peptide 1 in obese type 2 diabetic patients. Diabetes Care 27, 1077-1080.

Derosa, G., Maffioli, P., Sahebkar, A., 2015 Dec 30. Improvement of plasma adiponectin, leptin and C-reactive protein concentrations by orlistat: a systematic review and meta-analysis. Br. J. Clin. Pharmacol. http://dx.doi.org/10.1111/ bcp. 12874.

Dombrowski, S.U., Knittle, K., Avenell, A., Araújo-Soares, V., Sniehotta, F.F., 2014. Long term maintenance of weight loss with non-surgical interventions in obese adults: systematic review and meta-analyses of randomized controlled trials. BMJ 348 g2646 http://dx.doi.org/10.1136/bmj.g2646.

Douglas, I.J., Langham, J., Bhaskaran, K., Brauer, R., Smeeth, L., 2013. Orlistat and the risk of acute liver injury; self controlled case series study in UK Clinical Practice Research Datalink. BMJ 346 f1936.

EFSA Panel on Dietetic Products, 2010. Nutrition and Allergies (NDA). Scientific Opinion on the substantiation of health claims related to konjac mannan (glucomannan) and reduction of body weight (ID 854,1556, 3725), reduction of post-prandial glycaemic responses (ID 1559), maintenance of normal blood glucose concentrations (ID 835, 3724), maintenance of normal (fasting) blood concentrations of triglycerides (ID 3217), maintenance of normal blood cholesterol concentrations (ID 3100, 3217), maintenance of normal bowel function (ID 834, 1557, 3901) and decreasing potentially pathogenic gastrointestinal microorganisms (ID 1558) pursuant to Article 13(1) of Regulation (EC) No 1924/20061. EFSA J. 8 (10), 1798.

Filippatos, T.D., Derdemezis, C.S., Gazi, I.F., Nakou, E.S., Mikhailidis, D.P., Elisaf, M.S., 2008. Orlistat-associated averse effects and drug interactions. A critical review. Drug Saf. 31, 53-65.

Grube, B., Chong, P.W., Alt, F., 2015. Uebelhack R.Weight maintenance with Litramine (IQP-G-002AS): a 24-week double-blind, randomized, placebocontrolled study. J. Obes. 2015, 953138. http://dx.doi.org/10.1155/2015/953138. 
Grube, B., Chong, P.W., Lau, K.Z., Orzechowski, H.D., 2013. A natural fiber complex reduces body weight in the overweight and obese: a double-blind, randomized, placebo-controlled study. Obesity 21, 58-64. http://dx.doi.org/10.1002/ oby. 20244.

Grube, B., Chong, W.-F., Chong, P.W., Riede, L., 2014. Weight reduction and maintenance with IQP-PV-101: a 12-week randomized controlled study with a 24week open label period. Obesity 22, 645-651.

Hauptman, J., Jeunet, F., Hartmann, D., 1992. Initial studies in humans with the novel gastrointestinal lipase inhibitor Ro 18-0647 (tetrahydrolipstatin). Am. J. Clin. Nutr. 55 (Suppl. 1), 309S-313S.

Heymsfield, S.B., Segal, K.R., Hauptman, J., Lucas, C.P., Boldrin, M.N., Rissanen, A., Wilding, J.P., Sjöström, L., 2000. Effects of weight loss with orlistat on glucose tolerance and progression to type 2 diabetes in obese adults. Arch. Intern Med. $160,1321-1326$.

Jacob, S., Rabbia, M., Meier, M.K., Hauptman, J., 2009. Orlistat 120 mg improves glycaemic control in type 2 diabetic patients with or without concurrent weight loss. Diabetes Obes. Metab. 11, 361-371.

Johansson, K., Neovius, K., DeSantis, S.M., Rössner, S., Neovius, M., 2009. Discontinuation due to adverse events in randomized trials of orlistat, sibutramine and rimonabant: a meta-analysis. Obes. Rev. 10, 564-575.

Jordan, J., Astrup, A., Engeli, S., Narkiewicz, K., Day, W.W., Finer, N., 2014. Cardiovascular effects of phentermine and topiramate: a new drug combination for the treatment of obesity. J. Hypertens. 32, 1178-1188. http://dx.doi.org/10.1097/ HJH.0000000000000145.

Kelley, D.E., Kuller, L.H., McKolanis, T.M., Harper, P., Mancino, J., Kalhan, S., 2004. Effects of moderate weight loss and orlistat on insulin resistance, regional adiposity, and fatty acids in type 2 diabetes. Diabetes Care 27, 33-40.

Kwan, T., Chadban, S., Mckenzie, P., Saunders, J.R., 2013. Acute oxalate nephropathy secondary to orlistat-induced enteric hyperoxaluria. Nephrology 18, $241-242$.

Monami, M., Dicembrini, I., Nardini, C., Fiordelli, I., Mannucci, E., 2014. Effects of glucagon-like peptide- 1 receptor agonists on cardiovascular risk: a metaanalysis of randomized clinical trials. Diabetes Obes. Metab. 16, 38-47. http:// dx.doi.org/10.1111/dom.12175.

Muls, E., Kolanowski, J., Scheen, A., Van Gaal, L., 2001. The effects of orlistat on weight and on serum lipids in obese patients with hypercholesterolemia: a randomized, double-blind, placebo-controlled, multicenter study. Int. J. Obes. Relat. Metab. Disord. 25, 1713-1721.

Norris, S.L., Zhang, X., Avenell, A., Gregg, E., Schmid, C.H., Lau, J., 2005. Pharmacotherapy for weight loss in adults with type 2 diabetes mellitus. Cochrane Database Syst. Rev. 1. CD004096.

Padwal, R., Kezouh, A., Levine, M., Etminan, M., 2007. Long-term persistence with orlistat and sibutramine in a population-based cohort. Int. J. Obes. 31, 1567-1570.

Pi-Sunyer, X., Astrup, A., Fujioka, K., Greenway, F., Halpern, A., Krempf, M., Lau, D.C.W., le Roux, C.W., Ortiz, R.V., Jensen, C.B., Wilding, J.P.H., for the SCALE Obesity and Prediabetes NN8022-1839 Study Group, 2015. A randomized, controlled trial of $3.0 \mathrm{mg}$ of liraglutide in weight management. N. Engl. J. Med. $373,11-22$.

Richelsen, B., Tonstad, S., Rössner, S., Toubro, S., Niskanen, L., Madsbad, S., Mustajoki, P., Rissanen, A., 2007. Effect of orlistat on weight regain and cardiovascular risk factors following a very-low-energy diet in abdominally obese patients. Diabetes Care 30, 27-32.

Rucker, D., Padwal, R., Li, S.K., Curioni, C., Lau, D.C., 2007. Long term pharmacotherapy for obesity and overweight: updated meta-analysis. BMJ 335, 1194-1199.
Scheen, A.J., 2015. Pharmacodynamics, efficacy and safety of sodium - glucose cotransporter type 2 (SGLT2) inhibitors for the treatment of type 2 diabetes mellitus. Drugs 75, 33-59.

Shyangdan, D.S., Royle, P.L., Clar, C., Sharma, P., Waugh, N.R., 2010. Glucagon-like peptide analogues for type 2 diabetes mellitus: systematic review and metaanalysis. BMC Endocr. Disord. 10, 20. http://dx.doi.org/10.1186/1472-6823-10-20.

Siebenhofer, A., Jeitler, K., Horvath, K., Berghold, A., Siering, U., Semlitsch, T., 2013. Long-term effects of weight-reducing drugs in hypertensive patients. Cochrane Database Syst. Rev. 3. CD007654. http://dx.doi.org/10.1002/14651858. CD007654.pub3.

Sood, N., Baker, W.L., Coleman, C.I., 2008. Effect of glucomannan on plasma lipid and glucose concentrations, body weight, and blood pressure: systematic review and meta-analysis. Am. J. Clin. Nutr. 88, 1167-1175.

Svendsen, M., Helgeland, M., Tonstad, S., 2009. The long-term influence of orlistat on dietary intake in obese subjects with components of metabolic syndrome. J. Hum. Nutr. Diet. 22, 55-63.

Tiikkainen, M., Bergholm, R., Rissanen, A., Aro, A., Salminen, I., Tamminen, M., Teramo, K., Yki-Järvinen, H., 2004. Effects of equal weight loss with orlistat and placebo on body fat and serum fatty acid composition and insulin resistance in obese women. Am. J. Clin. Nutr. 79, 22-30.

Torgerson, J.S., Hauptman, J., Boldrin, M.N., Sjöström, L., 2004. XENical in the prevention of diabetes in obese subjects (XENDOS) study: a randomized study of orlistat as an adjunct to lifestyle changes for the prevention of type 2 diabetes in obese patients. Diabetes Care 27, 155-161.

Udani, J., Singh, B.B., 2007. Blocking carbohydrate absorption and weight loss: a clinical trial using a proprietary fractionated white bean extract. Altern. Ther. Health Med. 13, 32-37.

Uebelhack, R., Busch, R., Alt, F., Beah, Z.M., Chong, P.W., 2014. Effects of cactus fiber on the excretion of dietary fat in healthy subjects: a double blind, randomized, placebo-controlled, crossover clinical investigation. Curr. Ther. Res. Clin. Exp. 76, 39-44. http://dx.doi.org/10.1016/j.curtheres.2014.02.001.

Wang, T., Gou, Z., Wang, F., Ma, M., Zhai, S.D., 2014. Comparison of GLP-1 analogues versus sitagliptin in the management of type 2 diabetes: systematic review and meta-analysis of head-to-head studies. PLoS One 9 (8), e103798. http:// dx.doi.org/10.1371/journal.pone.0103798. Aug 4.

Yancy Jr., W.S., Westman, E.C., McDuffie, J.R., Grambow, S.C., Jeffreys, A.S., Bolton, J., Chalecki, A., Oddone, E.Z., 2010. A randomized trial of a low-carbohydrate diet vs orlistat plus a low-fat diet for weight loss. Arch. Intern Med. 170, 136-145.

Yanovski, S.Z., Yanovski, J.A., 2015. Naltrexone extended-release plus bupropion extended-release for treatment of obesity. JAMA 313, 1213-1214. http:// dx.doi.org/10.1001/jama.2015.1617.

Yanovski, S.Z., Yanovski, J.A., 2014. Long-term drug treatment for obesity. A systematic and clinical review. JAMA 311, 74-86.

Zalewski, B.M., Chmielewska, A., Szajewska, H., Keithley, J.K., Li, P., Goldsby, T.U., Allison, D.B., 2015a. Correction of data errors and reanalysis of "The effect of glucomannan on body weight in overweight or obese children and adults: a systematic review of randomized controlled trials". Nutrition 31, 1056-1057. http://dx.doi.org/10.1016/j.nut.2015.02.008.

Zalewski, B.M., Chmielewska, A., Szajewska, H., 2015b. The effect of glucomannan on body weight in overweight or obese children and adults: a systematic review of randomized controlled trials. Nutrition 31. http://dx.doi.org/10.1016/ j.nut.2014.09.004, 437-42.e2.

Zinman, B., Waner, C., Lachin, J.M., Fitchett, D., Bluhmki, E., Hantel, S., Mattheus, M., Devins, T., Johansen, O.E., Woerle, H.J., Broedl, U.C., Inzucchi, S.E., 2015. EMPAREG OUTCOME Investigators. Empagliflozin, cardiovascular outcomes, and mortality in type 2 diabetes. N. Engl. J. Med. 373, 2117-2128. 